\title{
ARTICLES
}

\section{Who Must Presume Whom to Be Innocent of What?}

\author{
Antony Duff
}

\section{Presuming Innocence in and Beyond the Criminal Trial}

The presumption of innocence (PoI) plays an apparently unassailable role in the rhetoric that surrounds the criminal trial.

'Throughout the web of the English Criminal Law, one golden thread is always to be seen, that it is the duty of the prosecution to prove the prisoner's guilt.' $^{1}$

'The principle that there is a presumption of innocence in favor of the accused is the undoubted law, axiomatic and elementary. ${ }^{2}$

'Everyone charged with a criminal offence shall be presumed innocent until proved guilty according to law.'3

If we are to understand the meaning and implications of this presumption (or presumptions), however, we must address several questions. What is to be presumed, by whom, of whom? What is the effect of that presumption? What can defeat it?

In the PoI's most familiar context, the criminal trial, initial answers to these questions are easy. The official or body who is to reach the verdict (the judge(s), the jury) is to presume, of the defendant, that he is innocent of the offence for which he is being tried. ${ }^{4}$ The presumption protects the defendant against conviction and punishment for that crime unless it is defeated; what defeats it is proof of guilt to the requisite standard.

* Earlier versions of this paper were delivered at conferences in Aberdeen Law School, RutgersCamden Law School, and Macquarie University: I'm grateful for the helpful comments I received at these meetings. I am also grateful to Anne Ruth Mackor for helpful comments on a penultimate draft.

1 Woolmington v. DPP [1935] A.C. 462, at 481, per Viscount Sankey.

2 Coffin v. United States 156 U.S. 432 (1895), at 453.

3 European Convention on Human Rights, Art. 6(2); see also International Covenant on Civil and Political Rights, Art. 14(2).

4 Since most defendants and offenders are male, I will use the masculine pronoun throughout. 
Even in this familiar context, of course, questions arise about the proper meaning and the precise implications of the PoI. To mention just two, is it consistent with the PoI to lay on the defendant any formal burden of proof, whether evidential or persuasive, in relation to matters bearing on the verdict: to hold, for instance, that if it is proved that the defendant committed the offence, he must then prove (or at least adduce evidence of) any defence that he wishes to offer, if he is to avoid conviction $?^{5}$ Does the PoI apply to sentencing: is it consistent with the PoI for a convicted offender's sentence to be determined by aggravating features of the crime that were not proved in the trial? ${ }^{6}$

However, such questions are not my concern here: I focus in this paper on the question of whether the, or a, PoI has a role beyond the confines of the criminal trial. Some argue that the PoI operates only within the trial, as a rule that lays the burden of proof on the prosecution. ${ }^{7}$ Others argue that it applies more broadly: for instance that it incorporates all the demands of due process; ${ }^{8}$ that it applies to pre-trial detention as well as to the trial $;^{9}$ that it is implicated if samples of DNA are retained even from those who have not been convicted; ${ }^{10}$ that it might have implications for the process of criminalization; ${ }^{11}$ that it is an aspect of a broad 'principle of civility' that governs our civic dealings with each other. ${ }^{12}$

There are considerations that favour each of these readings, narrow or wide, of the PoI. Advocates of a narrow reading can argue that this gives the PoI a tolerably clear, determinate meaning, expressing what can be plausibly portrayed as a categorical right: more expansive readings risk turning it into empty rhetoric that can do no substantial work in constraining the exercise of state power. Advocates of a wider reading can argue that if we are to understand the significance of the PoI within the criminal trial, we must see it as an expression of deeper values that should structure the state's dealings with its citizens; and that since the question of whether we are criminally guilty or innocent bears on the treatment we can

5 Such 'burden-shifting' provisions have caused particular problems for English courts grappling with the implications of Art. 6(2): see Andrew Stumer, The Presumption of Innocence: Evidential and Human Rights Perspectives (Oxford: Hart Publishing, 2010), chs. 1, 6.

6 See, e.g., Blakely v. Washington 124 S. Ct. 2531 (2004); US v. Booker 125 S. Ct. 738 (2005).

7 See, e.g., Larry Laudan, 'The Presumption of Innocence: Material or Probatory?,' Legal Theory 11 (2005): 333, at 336-7; Stumer, The Presumption of Innocence; also Bell v. Wolfish 441 US 520 (1979).

8 See Hock Lai Ho, 'The Presumption of Innocence as a Human Right,' in Criminal Evidence and Human Rights, ed. Paul Roberts and Jill Hunter (Oxford: Hart Publishing, 2012), 259.

9 See. e.g.. Shima Baradaran, 'Restoring the Presumption of Innocence,' Ohio State Law Journal 72 (2011): 723; Lonneke Stevens, 'Pre-Trial Detention: The Presumption of Innocence and Art. 5 of the European Convention on Human Rights Cannot and Does Not Limit its Increasing Use,' European Journal of Crime, Criminal Law and Criminal Justice 17 (2009): 165.

10 See Liz Campbell, 'A Rights-based Analysis of DNA Retention: Non-conviction Databases and the Liberal State,' Criminal Law Review (2010): 889.

11 See Patrick Tomlin, 'Extending the Golden Thread? Criminalisation and the Presumption of Innocence,' Journal of Political Philosophy 21 (2013): 44.

12 See Dale A. Nance, 'Civility and the Burden of Proof,' Harvard Journal of Law \& Public Policy 17 (1994): 647. 
expect both from the state and from our fellow citizens in contexts well beyond the criminal trial, the PoI must be relevant in these other contexts too. ${ }^{13}$ The PoI as it functions in the particular context of a criminal trial protects a particular group of people, those who appear in court as defendants, against a particular kind of state coercion or imposition - against conviction and punishment for a criminal offence. But we face other kinds of coercion, other kinds of imposition, as the state exercises its powers in the investigation and prevention of crime (we will discuss some of these in what follows): surely we can expect to be protected against these other kinds of coercive imposition as well - protected, we might expect, by something like the PoI.

Perhaps, however, this controversy is to some extent misconceived, at least if our concern is with normative theorizing about the PoI. The controversy would matter if we had to assume that there is such a thing as 'the PoI': a single principle whose scope we must determine. That assumption makes sense if we are interpreting a specific statute - if, for instance, our concern is with the legal interpretation of Article 6(2) of the European Convention on Human Rights (ECHR): we must talk then of 'the PoI', as the principle enshrined in that Article, and determine its proper scope. ${ }^{14}$ But if we are not thus bound to a specific statutory provision, we can take a more relaxed approach, and talk of not one but many PoI: of different presumptions made by and about different people in different normative contexts, with different effects, defeasible in different ways. Such presumptions will be connected to each other in a larger web of values; but we will not need to argue that they can be unified into a single PoI. We can recognize a distinctive PoI that applies in the criminal trial: but we will not suppose that this is the only context in which we can talk of a demand that people be presumed innocent.

This is the strategy that I will pursue. One could explore the role of a PoI in a wide range of social contexts: we could ask what kind of 'innocence' family members, spouses, friends, colleagues, should presume of each other, to what effect, subject to what kinds of defeat. But I will limit my attention to contexts in which we must deal with each other, and with the state, in relation to the criminal law. More precisely, I will consider only presumptions that should be made by citizens about each other, and by a state about its citizens, in their civic dealings; presumptions of innocence of what the law defines as crimes, which protect us against kinds of coercion that actual or suspected criminal conduct is thought to

13 Nor indeed is there a sharp distinction between 'the criminal trial' and other contexts in which the, or a, PoI might be relevant. The ECtHR has held that the PoI applies in any proceedings closely 'linked to the issue of criminal responsibility' (Hammern v. Norway; quoted in Tom Hickman and Faisal Saifee, 'Hammern v Norway, O v Norway, Ringvold v Norway and Y v Norway,' European Human Rights Law Review 5 (2003): 539-46, at 542); this includes proceedings in which an acquitted defendant applies for his costs, but not necessarily proceedings in which a civil compensation order is made against someone acquitted on a criminal charge.

14 We might also be tempted to stretch the scope of the provision so as to increase the 'real protections against state power' that it provides (see Victor Tadros and Stephen Tierney, 'The Presumption of Innocence and the Human Rights Act,' Modern Law Review 67 (2004): 402, at 413-14). 
justify; and presumptions that are a matter of how we behave, rather than of our beliefs or attitudes. I might believe that another person is guilty of a crime, and therefore feel hostility towards him; I might break off our friendship, or shun him at social events, or cease doing business with him: whatever the ethics of such behaviour, it does not infringe any PoI of the kind that concerns me here. But if an official deals with a citizen as if he was guilty of a crime, or if other citizens exclude him from ordinary civic amenities as being guilty (they daub his house with accusatory graffiti, or exclude him from public spaces): a PoI of the kind I am concerned with here is implicated. ${ }^{15}$

We can understand the different presumptions of innocence that protect us in different contexts, I will suggest, by looking at the rights and responsibilities that attach to the various roles we play in relation to the criminal law. A preliminary comment is, however, necessary.

Any exercise in legal theory involves the danger of parochialism - of supposing that what is true of 'our' law here and now must be true of all law everywhere at all times. This danger is perhaps especially acute in the context of criminal law: it is too easy for normative theorists to offer accounts that reflect and make good sense of their own legal systems, and to suppose that those accounts must apply universally. One way to meet the challenge of parochialism is to try to develop a truly universal account, free from all local bias. I do not know how viable this approach is - how much one can say about 'criminal law' as such that applies to anything that counts as a system of criminal law. That is, anyway, not how I will meet the challenge. I will offer an account that is avowedly parochial: it flows from the common law systems with which I am familiar, and from the political values of a familiar kind of liberal republicanism. I believe that this account makes good normative sense of the kinds of legal system in which it is grounded, but also that the values to which it appeals reach more broadly, at least as far as other polities that aspire to be liberal democracies - even if the institutional instantiation of those values will differ in different systems. It will be a matter for further discussion to work out how far different kinds of criminal process reflect different ways of giving institutional form to the same underlying values; and how far they reflect deeper differences in values - in which case we must also ask what room there is for argument about such differences. For the moment, however, I simply confess that what follows is developed from an Anglo-American perspective, and ask readers to consider how far it also makes normative sense, if necessary given some relatively superficial modifications, of the systems from within which they work.

15 I talk of how citizens should treat each other, and be treated by the state. Non-citizens also have dealings with the criminal law; they must be protected by any PoI that protects citizens. I talk of citizens because they are the criminal law's primary addressees: we can understand the position of non-citizens by seeing them as guests in the polity. See my 'Responsibility, Citizenship and Criminal Law,' in Philosophical Foundations of Criminal Law, ed. R. A. Duff and Stuart P. Green (Oxford: Oxford University Press, 2011), 125. 


\section{Defendants' Rights and Responsibilities}

Whatever controversies there are about the scope of 'the PoI', it protects the defendant in a criminal trial, against the legal burden of being convicted and punished: that burden can be imposed on them only if their guilt is proved 'according to law.' More generally, defendants at trial are protected by a range of principles and rights - those captured in the idea of a 'fair trial.' But defendants also incur certain burdens - material, psychological and normative - in virtue of their role as defendants. There are the material burdens of preparing a defence and attending the trial, and the psychological burdens involved in the process, including the fear of conviction that can disturb even the innocent in a human, i.e., fallible, system of criminal justice; but my main interest here is in the normative burdens, the duties and responsibilities, that one acquires by becoming a defendant.

The defendant is required to appear in person to stand trial, at least in more serious cases: this marks an exercise of the state's coercive power, since a defendant who fails to appear is liable to be arrested and forcibly brought to court. ${ }^{16}$ The defendant is expected, although not forced, to enter a plea of 'Guilty' or 'Not Guilty' in response to the charge, ${ }^{17}$ and is required to behave appropriately during the trial. He is not legally required to say anything in his own defence, but risks conviction if he does not respond to the prosecution case, or offer a defence if the prosecution proves the commission of the offence. If he is convicted, he is required to accept the court's verdict (unless there are grounds for appeal) and to undertake or undergo whatever punishment is imposed. 'Defendant' is thus a distinctive normative role, with its own particular rights and responsibilities.

Once a person becomes a defendant the PoI protects him against the burden of unjustified conviction. But surely we should also be protected, before we become defendants, against the unwarranted imposition of the burdens of becoming a defendant - of being put on trial. And we are indeed protected. We are protected against our fellow citizens, by the fact that private prosecutions, if possible at all, are subject to control by the state: in England, the Director of Public Prosecutions has the power to take over, and then discontinue, a private prosecution. ${ }^{18} \mathrm{We}$ are protected against unwarranted prosecutions by the state's officials. This used to be the function of committal proceedings in English criminal courts; ${ }^{19}$ it is now covered by the Code for Crown Prosecutors, which requires prosecutors to proceed with a case only when there is 'a realistic prospect of conviction.'20 One

16 In England, the 'requirement' that defendants appear for trial may not be enforced in summary trials (Magistrates' Courts Act 1980, ss. 11-13). It is enforced in trials on indictment (Bail Act 1976, s. 7).

17 On the 'peine forte et dure' by which pleas used to be extracted, see Andrea Mckenzie, 'This Death Some Strong and Stout Hearted Man Doth Choose,' Law and History Review 23 (2005): 279.

18 Prosecution of Offences Act 1985, s. 6(2).

19 See John Sprack, Emmins on Criminal Procedure, 9th ed. (Oxford: Oxford University Press, 2002), ch. 12.

20 Code for Crown Prosecutors (www.cps.gov.uk/publications/docs/code2010english.pdf), s. 4.5. 
rationale for such provisions is to prevent the waste of public resources in pursuing prosecutions that have no reasonable prospect of success; but they also reflect a PoI. As citizens, we should not have to undertake the normative burden of becoming a criminal defendant unless there is evidence of our guilt strong enough to amount to a case to answer: we should be presumed to be innocent of crime until there is sufficient evidence of our guilt.

This is not the PoI that operates in a criminal trial. The presumption is to be made, not by a court, but by a prosecuting authority. It is made not about a defendant (there is no defendant yet) but about a citizen (albeit one suspected of crime). The effect of the presumption is that he is protected, not against conviction, but against having to stand trial. What rebuts it is not proof of his guilt (that is a matter for the trial), but sufficient evidence of guilt to constitute a case to answer. Such evidence does not defeat the PoI: it does not warrant treating the person as guilty. But it qualifies the PoI: for were the presumption left undisturbed, were the person still to be treated as innocent, there could be no justification for putting him on trial. He must be treated by the prosecutor, or by a court in a committal hearing, neither just as an innocent (who should be freed from further proceedings), nor as guilty, but as a citizen against whom there is reasonable suspicion of guilt: it is that suspicion, the evidence grounding a reasonable prospect of conviction, that warrants requiring the person to take on this distinctive normative role of 'defendant', and the burdens that it brings.

This sketch of the defendant's rights and responsibilities highlights three general points. First, we can make progress in understanding both the PoI (plural), and the operations of a system of criminal justice generally, by looking at the normative roles that figure in such a system, and the rights and responsibilities that such roles involve. We have looked so far at defendants (and thus also at prosecutors): other relevant roles include victim, witness, police officer, suspect, convicted offender and 'ex-offender' - though in this paper I will only have space to discuss the role of 'ex-offender.'

Second, in looking at these roles, we must ask not only what may or may not be done (by officials or fellow citizens) to those who occupy them, but at what we can require from them: not just at rights and burdens, but at duties and responsibilities. This is familiar in relation to some roles, such as those of police and prosecutors, but is not always salient in discussions of other roles. We often talk, for instance, about what we or the law should do to or for victims - but not enough about their responsibilities as victims, or about what we may expect from them. ${ }^{21}$ We talk about what we may or should do to convicted offenders, but not about what we can properly require of them - what responsibilities might attach to that

21 But see S.E. Marshall, 'Victims of Crime: Their Station and its Duties,' in Managing Modernity: Politics and the Culture of Control, ed. Matt Matravers (London: Routledge, 2004), 104. 
distinctive role. ${ }^{22}$ The same is true of defendants in criminal trials: we should see them, not merely as objects of a judicial inquiry that aims to determine whether they are guilty of the crime charged, but as active participants in the process: the defendant is summoned to answer to the charge (and so accept the court's authority), to answer for his conduct if it is proved that he committed the crime, and to accept (and respond appropriately to) the court's verdict. ${ }^{23}$

Third, while a distinctive PoI operates within the criminal trial to protect defendants from unwarranted conviction and punishment unless guilt is proved 'according to law,' we can also identify another PoI that operates earlier in the process that leads from reported crime to the criminal trial: a PoI that protects all citizens against having the burdensome normative role of defendant imposed on them, unless there is sufficient evidence of their guilt. Perhaps it would be more accurate to say that this PoI protects those suspected of crime (for in any noncorrupt legal system, only those suspected of crime face the prospect of becoming defendants); but it can best be understood, I will argue, as expressing a broader PoI that protects all citizens.

Before turning to that argument, a word should be said about what becomes of the role of defendant after the trial at which he is convicted or acquitted.

If he is convicted, he is an offender. If he committed the crime for which he was tried, he was in fact an offender from that moment: but given the PoI, he may be treated as an offender only once he is convicted; the role of 'offender,' within the public realm of the criminal law, is that of 'convicted offender.' As a convicted offender, he is liable to have punitive measures imposed on him; but his role still involves active duties and responsibilities. An obvious point is that punishments are not typically imposed on passive recipients: the offender is required to be active - to pay a fine, to undertake the community service that constitutes his punishment, to attend meetings with a probation officer. Even imprisonment has an active dimension: for in some systems those sentenced to imprisonment may be required to present themselves on the specified date to serve their sentence; even in (less civilized) jurisdictions in which those sentenced to imprisonment are just taken from court to prison, there are requirements about how they behave in prison. A deeper point is that on some views punishment is understood not simply as something done to offenders, but as something that offenders ought themselves to undertake, as agents: what is required of them is that they 'pay their debt' to those whom they wronged; and although if someone refuses to pay his

22 But see Jacob Adler, The Urgings of Conscience (Philadelphia: Temple University Press, 1992); Victor Tadros, The Ends of Harm (Oxford: Oxford University Press, 2011). One merit of the approach taken by advocates of 'restorative justice' is that they seek a more active role for both victims and perpetrators (even if one might disagree with their account of what such roles should be). See famously Nils Christie, 'Conflicts as Property,' British Journal of Criminology 17 (1977): 1.

23 For this view of the criminal trial, see Antony Duff, Lindsay Farmer, Sandra Marshall, and Victor Tadros, The Trial on Trial (3): Towards a Normative Theory of the Criminal Trial (Oxford: Hart Publishing, 2007). 
debt it might be exacted from him without his agency, the initial demand is that he pay the debt through his own agency. ${ }^{24}$

If the defendant is acquitted, the PoI has not been defeated, and so remains in place. He is no longer a defendant, since the trial is over. Nor can he still be treated by the state (or by his fellow citizens) as a suspect: the suspicions that led to him becoming a defendant have been formally tested in court, and have not survived that scrutiny. That is why the European Court of Human Rights (ECtHR) has held that it is inconsistent with Article 6(2) of the ECHR for a court to reject an acquitted defendant's claim for costs on the grounds that he has not established his innocence. ${ }^{25}$

Laudan objects that the 'Not Guilty' verdict, in systems that allow only two verdicts (and set a demanding standard of proof for convictions), 'will be neither very informative nor very exculpatory': it means only that guilt has not been proved to the requisite standard, and leaves an acquitted defendant with most of 'the stigma already arising from being arrested, charged with, and tried for, a crime. ${ }^{26}$ He suggests instead a four-verdict system: courts would find a defendant 'guilty,' or 'probably guilty,' or 'probably innocent,' or 'innocent.'

Now someone who has been acquitted is in fact likely to suffer social stigma, in the eyes of those who 'know' that the acquitted are very often actually guilty; the law itself sometimes allows a charge on which a person was acquitted to count against him subsequently. ${ }^{27}$ Such social reactions and such legal provisions, however, are manifestly inconsistent with the PoI. If a person is presumed innocent, that presumption remains effective until it is defeated; an acquittal marks a formal judgment that it has not been defeated; an acquitted defendant must be presumed, as he was presumed during his trial, to be innocent of the charge. If we take the PoI seriously, an acquittal is as 'informative' as it needs to be: it tells us that the PoI has not been defeated. True, it is not 'exculpatory': but, given the PoI,

See my Punishment, Communication and Community (New York: Oxford University Press, 2001); and Christopher Bennett, The Apology Ritual (Cambridge: Cambridge University Press, 2008).

25 See n. 13 above.

26 Larry Laudan, 'Need Verdicts Come in Pairs?,' International Journal of Evidence and Proof 14 (2010): 1 , at 2 .

27 Laudan, 'Need Verdicts Come in Pairs?,' 6. See also, for just one example, Criminal Procedure (Scotland) Act 1995 s. 210C(1): alleged past criminal behaviour can inform judgments of dangerousness even if the person was acquitted. 
no exculpation is needed: ${ }^{28}$ what matters is the absence of inculpation, of proof of guilt, since that leaves the PoI intact. ${ }^{29}$

Such a response to Laudan is, however, too quick, for two reasons. First, it presupposes not only that the (or a) PoI should operate beyond the trial, but also that it should be as hard to rebut such a broader PoI as it is to rebut the PoI in the trial: not only must the trial court presume the defendant to be innocent unless his guilt is proved to the appropriate standard; other legal bodies and officials, and his fellow citizens, must presume him innocent unless such proof is provided. But why should we give the PoI so broad and demanding a reach?

Second, we have already identified a normative role that qualifies the PoI. A defendant is not simply presumed to be innocent: he is someone facing a criminal charge that is backed by strong evidence of guilt. Similarly, someone who has not yet been charged with a crime, but who is under official investigation as a suspect, plays a distinctive normative role that brings material and normative burdens (being questioned by the police, for instance, or having one's property searched), and that involves being treated, if not as guilty, then at least as far from presumptively innocent. If these roles of suspect and defendant are consistent with the PoI, would it not also be consistent to expand the role of 'suspect' to include those who were not convicted at their trial, but who have failed to establish their probable innocence? We should set a high standard of proof before we impose the role of 'convicted offender' on anyone: but why should we talk and act counterfactually, as if everyone who is not convicted is innocent; why should we not operate with a more nuanced PoI? The PoI would still be defeated only by proof of guilt: only then would it be replaced by a judgment of guilt. But just as it is qualified when a person becomes a suspect or defendant, why should that qualification not persist if the person's (probable) innocence is not established?

The first point is unpersuasive: the criminal court that presumes a defendant's innocence is not an isolated body whose decisions have no implications for others. Its decisions, first, bind other branches of law and government: if a court acquits the defendant, other officials should not publicly doubt that verdict or portray the acquitted defendant as guilty. ${ }^{30}$ Second, in a democracy the court acts in the name of the whole polity: we call the defendant to answer to the charge of

28 To be more precise, exculpation is needed only if the prosecution has inculpated the defendant by proving that he committed the offence: see my 'Presuming Innocence,' in Principles and Values in Criminal Law and Criminal Justice, ed. Lucia Zedner \& Julian Roberts (Oxford: Oxford University Press, 2012), 51.

29 Suppose that the defendant is acquitted 'on a technicality' - because although there was overwhelmingly convincing evidence of his guilt, for instance, it was excluded from the trial because it had been illegally obtained? (Thanks to Anne Ruth Mackor for pressing this question.) I cannot discuss here the various kinds of procedural requirement, including those to do with the exclusion of evidence, that might hinder proof of guilt (but see Duff et al., The Trial on Trial, ch. 8): all I would say here is that if we are right to exclude illegally obtained evidence, the defendant must indeed still enjoy the protection of the PoI: he has not been 'proved guilty according to law.'

See Ho, 'The Presumption of Innocence as a Human Right,' 263-66. 
criminal wrongdoing; and we condemn his conduct if he is convicted. ${ }^{31}$ The court's presumption of the defendant's innocence is our collective presumption; the court's verdict that the presumption is undefeated is our collective verdict: it would be inconsistent for us, collectively, not to abide by that verdict. ${ }^{32}$ But this does not undermine the second point noted above: we could operate with a more nuanced version of the PoI, which permits suspicion to survive a formal finding that the defendant's guilt has not been proved.

It might be argued that this would mark a realistic acceptance of the actualities of civic life. We know (or think we know) that many who are acquitted were actually guilty of the crimes with which they were charged, and that many offenders reoffend: so why should not our civic dealings with each other, and our treatment by state officials, reflect that knowledge? Whilst defendants should be able to clear their names and secure an 'Innocent' verdict, we could also recognize a role of 'Suspected though not proved guilty.'33 This might indeed be encouraged by the recognition that we have not just one PoI but several, operating with different effects in different contexts, and subject to different kinds of defeat. We can preserve the PoI in the criminal trial, to protect defendants against conviction and punishment until guilt is proved, and insist more generally that a person should be treated as guilty of crime only if his guilt is proved; but we can operate with more nuanced varieties of PoI outside the trial, and accept that they may be qualified by suspicion without being defeated.

A thorough assessment of this suggestion would depend on a more detailed account of its implications. We know what belongs with being a defendant or a pre-trial suspect: what extra burdens this brings, what difference it makes to one's treatment. But what are the normative implications of this new role of continuing suspect? How would officials, or fellow citizens, be permitted to behave towards me in virtue of my status as a 'continuing suspect'? But even without answering such questions, we can see why we should reject any such suggestion, as inconsistent with how we should aspire to treat each other as fellow citizens. For basic to citizenship in a well-functioning republic is a modest kind of civic trust - a trust reflected in the PoI: but this status of continuing suspect would be inconsistent with such trust. Suspects and defendants do admittedly suffer some qualification of that trust: but their roles are strictly time-limited; they end with a trial and verdict, or with an official decision not to proceed with the case. To permit this open-ended, indefinitely extended role of 'continuing suspect' would be to abandon any attempt to preserve the principle of civic trust on which a civilized polity depends - the principle that citizens are entitled to be trusted until

31 See further my Punishment, Communication and Community, 56-68 on the 'common law.'

32 But bear in mind that, as I noted earlier, this concerns only our civic dealings with the defendant.

33 As implied by the Scottish 'Not Proven' verdict: see G.C. Gebbie, S.E. Jebens, \& A. Mura, 'Not Proven as a Juridical Fact in Scotland, Norway and Italy,' European Journal of Crime, Criminal Law and Criminal Justice 7 (1999): 262. 
they show, by their own conduct, that such trust is unwarranted. ${ }^{34}$ It is to the nature and implications of that trust that we must now attend.

\section{Civic Trust as a Presumption of Innocence}

The PoI is often discussed as if it allows only two kinds of status: either one is a proven guilty offender or one is a presumed innocent. As we have seen, however, the matter is more complex. Becoming a defendant qualifies any PoI, and brings with it duties that reflect such a qualification: I must answer to the charge, which I would not have to do were I still presumed innocent. But we are also protected by a PoI against being turned too hastily into defendants: prosecutors and courts should presume us to be innocent until there is evidence of guilt strong enough to warrant a trial.

This PoI, which protects us against becoming defendants, is one to which we are entitled as citizens: we can call it the civic PoI, to distinguish it from the PoI that operates in the trial. The civic PoI reflects the civic trust that we owe our fellow citizens. ${ }^{35}$ To talk of civic trust, or of a demand that we presume each other to be innocent, is not to say that we must go about our lives in a spirit of naive optimism: the fact that we lock our houses and cars, and install burglar alarms, and take other precautions against the possibility of being victimized, does not show that we have lost any sense of civic community (although it speaks to the extent to which citizens may be strangers to each other). Indeed, insofar as criminal punishment serves a deterrent purpose, our maintenance of a system of criminal law reveals that we do not fully trust each other to refrain from crime: for if we did, we would see no need for deterrence. But we owe it to each other to recognize each other as fellow citizens: not to assume in advance that others are enemies who might attack us. This modest trust shows itself in our demeanour as we walk the streets: in the fact that we do not usually cross the road to avoid others coming towards us, or take defensive precautions against them; in the fact that if someone approaches us, we do not assume that their intentions are hostile. If I approach someone to ask directions, and he reacts by avoiding me, or by taking up a defensive posture, or producing a weapon, I will feel insulted: not because he should realize that I, as an individual, am trustworthy, but because he has assumed, without any basis in my conduct, that I am not. Even a system of deterrent punishments involves a modest degree of trust: a system of law could not survive unless most refrained from crime without having to be deterred. ${ }^{36}$

That is also why it matters that neither decisions about whether to prosecute a suspect, nor the criminal trial itself, are delayed indefinitely or for long periods of time: the status of suspect, or defendant, creates some doubt about the person's innocence; such doubts must be speedily resolved.

35 See Nance, 'Civility and the Burden of Proof.'

36 The parochialism to which I have pleaded guilty is again in evidence here: the 'we' of whom I speak are those who are lucky enough to live in functioning polities in which such civic trust is possible. Where it is not possible, civic society is breaking down, as is the possibility of the rule of law as something other than the exercise of coercive power. 
To put the point in a slightly different way, the civic trust upon which we rely is a trust in each other, and in ourselves, to be reason-responsive: ${ }^{37}$ we treat each other as agents who can recognize, and guide their actions by, appropriate reasons for action. Those reasons are often moral reasons - in particular, moral reasons not to attack each other. But they also include the kinds of prudential reason on which deterrent punishment relies: we trust each other to be deterred by the prospect of future punishment.

Four points are worth noting here. First, to talk of 'civic trust', and of 'the civic PoI,' is to emphasize that our concern here is with the trust that we should display, the presumption that our conduct should express, in our dealings with each other simply as citizens. ${ }^{38}$ We are not concerned here with the kinds of trust or presumption that might be appropriate between, for instance, friends, or family members, or colleagues in particular professions or activities. Nor are we concerned with the kind of trust or presumptions that are appropriate when we begin to deal with others not merely as citizens, but as, for instance, merchants, bankers, doctors, or lawyers: when we are entering into transactions or relationships of such kinds, which make us particularly vulnerable to harm, we are entitled to look for assurances of trustworthiness. ${ }^{39}$

Second, while the PoI in the criminal trial is specific and retrospective, as a presumption of innocence of a specified alleged past offence, the civic PoI is general and prospective: we are to be presumed innocent not just of specific past crimes, but of future crimes in general. ${ }^{40}$ But this is not a puzzling extension: it would be odd to insist on presuming of a responsible person that he is innocent of specific past crimes, whilst treating him as someone who is very likely to offend.

Third, the kinds of crime-preventive measure that are most readily acceptable consist in precautions that make it difficult for someone to carry through a criminal endeavour, but that do not impinge on those who have not embarked on a crime. This is clearly true, for instance, of locking cars and of burglar alarms: typically (except when they malfunction), they hinder only someone attempting an illegal entry. Such precautions mark a sensible awareness that there are would-be criminals in our world, but do not mark an unwarranted presumption that any individual is a would-be criminal - by contrast with precautions that impinge on people who have not embarked on a criminal enterprise.

37 Reason-responsiveness is often, and plausibly, taken to be a defining feature of responsible agency: see, e.g., John Martin Fischer \& Mark Ravizza, Responsibility and Control (Cambridge: Cambridge University Press, 1998).

38 See text preceding n. 15 above.

39 See further text following n. 62 below.

40 Compare Jean Floud \& Warren Young, Dangerousness and Criminal Justice (London: Heinemann, 1981), 44, on a citizen's 'right to be presumed free of harmful intentions.' 
Fourth, some precautions do restrict people who have not embarked on crime: this is true of many species of 'situational crime prevention'; ${ }^{41}$ airport security measures provide another example. But these, if not unduly burdensome, may be acceptable so long as they are applied indiscriminately, to everyone (or to everyone who takes part in the relevant activity, such as air travel) - though there is of course ample room for argument about what counts as 'unduly burdensome.' Matters become morally more problematic when such precautions are applied selectively, targeted at particular groups whose members are deemed suspicious: we must ask whether the criteria of selection are appropriate, which is not just a question of whether they pick out those who are empirically more likely to be dangerous. ${ }^{42} \mathrm{~A}$ similar point applies to deterrent punishment: it is much easier to justify such a system if we can understand it not as system by which a law-abiding 'we' deter a criminally-minded 'them,' but as one by which we aim to persuade ourselves, as fallible humans, to refrain from conduct that we know to be wrongful. ${ }^{43}$

This modest civic PoI protects citizens against being treated as if they were guilty, either retrospectively of past crimes or prospectively of future crimes. But we have seen that it is qualified when someone becomes a criminal defendant: for to become a defendant is to have one's innocence put formally in doubt, on the basis of plausible evidence that one is guilty. So a more general question now arises: under what conditions, with what normative effects, is this civic PoI legitimately put into question: when, and to what ends, can it be qualified or defeated, allowing citizens to be treated by each other or by the state as guilty, or as suspects? We cannot tackle all aspects of that general question here: but to clarify its importance, and show how it can be answered by attending to some of the normative roles that we might find ourselves playing in relation to the criminal law, I will in the following two sections briefly discuss two such roles: that of defendant awaiting trial, and that of 'ex-offender' - someone who was convicted of a crime, and who has now completed his punishment.

\section{Defendants Awaiting Trial: Duties of Reassurance}

We have already noted the distinctive normative role of 'defendant' in a criminal trial - a role involving both rights and responsibilities. The defendant's role, however, begins before his trial, since there is typically some delay between becoming a defendant - being formally charged with an offence - and standing trial. Now courts could simply fix the trial date, and instruct the defendant to appear for trial on that date - on pain of being subject to arrest and sanctions if he fails to

41 See Andrew von Hirsch, David Garland, \& Alison Wakefield (eds.), Ethical and Social Perspectives on Situational Crime Prevention (Oxford: Hart, 2000).

42 See Air Transportation and Risk Management, Canadian Journal of Criminology \& Criminal Justice 48.3 (2006) - a special issue edited by J.-P. Brodeur.

43 Compare Andrew von Hirsch, Censure and Sanctions (Oxford: Oxford University Press, 1993), esp. ch. 2 . 
appear, or tries to subvert the trial process. But that is not what we do. Instead, the defendant must apply for bail if he wants to remain free pending his trial. He may be freed 'on his own recognizance,' simply by promising to appear for trial; or he may have to post bail - provide guarantees for a sum of money that will be forfeit if he does not appear for trial; further conditions may be attached to bail, concerning where he may live pending his trial, where he may travel, or whom he may meet; or bail may be refused, in which case he is remanded in custody until his trial. ${ }^{44}$ The grounds for denying bail are preventive: the court's concern is with the risk that the defendant will fail to appear for trial, or will commit offences while on bail, or will obstruct the course of justice. ${ }^{45}$

The imposition of such restrictions on defendants awaiting trial, either by detaining them or by imposing restrictive conditions on the grant of bail, does not strictly contradict the PoI that operates in the criminal trial: it does not strictly presume the defendant to be guilty of the offence for which he is to be tried; even an innocent defendant might be tempted to flee or to interfere with the course of justice. But, first, it is in tension with that PoI, since the empirical likelihood that the defendant will flee, or interfere with the trial process, or commit offences, is significantly affected by the likelihood that he is guilty of the offence charged: the court's judgement that restrictive bail conditions or a denial of bail are necessary must be affected by its judgement of how likely it is that the defendant is guilty. ${ }^{46}$ Second, such restrictions seem clearly inconsistent with the civic PoI discussed in section 3: if we really presumed a defendant to be innocent of both past and future crimes, we would have no reason to restrict or detain him.

However, we have seen that matters are not so simple: a defendant is not simply a citizen who must be presumed, by the courts and his fellows, to be innocent of criminal wrongdoing. For he has acquired a new normative status, as someone against whom plausible evidence of criminal wrongdoing has been laid; and that status brings with it new burdens and duties, and a qualification of the civic PoI. We have noted the responsibilities that attach to this role in a criminal trial; and I have argued elsewhere that we can also properly impose new duties on defendants who are awaiting trial. ${ }^{47}$ Those duties flow from the responsibilities that we have to reassure our fellow citizens of our good behaviour and our good intentions, in contexts in which there is reason to doubt them. ${ }^{48}$ One such context is the criminal trial: the evidence that the defendant committed an offence, which

See Andrew Ashworth \& Mike Redmayne, The Criminal Process, 4th ed. (Oxford: Oxford University Press, 2010), ch. 8.

45 See Bail Act 1976, s. 4, and Schedule 1 (specifying the grounds on which bail may be denied).

46 The 'strength of the evidence of his having committed the offence' is indeed one of the factors to which English courts must attend in deciding whether to grant bail: Bail Act 1976, s. 4, Schedule 1, Part I, para. 9.

47 'Pre-Trial Detention and the Presumption of Innocence,' in Prevention and the Limits of the Criminal Law, ed. Andrew Ashworth, Lucia Zedner, \& Patrick Tomlin (Oxford: Oxford University Press, 2013), 115.

48 See Peter Ramsay, The Insecurity State: Vulnerable Autonomy and the Right to Security in the Criminal Law (Oxford: Oxford University Press, 2012). 
justifies bringing him to trial, also gives us reason to suspect that he might abscond, or interfere with the trial process; for the role of defendant brings with it, not only burdens of the kinds noted above, but also temptations to try to avoid those burdens by fleeing or interfering. We may therefore legitimately require him to reassure us that he will appear for trial, and will not interfere with the process; and since mere words are cheap, we may require that he back up his reassurance with something more material - by providing a financial bond, or by accepting certain restrictions on his movements, to make his law-abiding intentions manifest. As a defendant, who has acquired a normative status which brings with it this justified suspicion of criminal wrongdoing, I show my respect for the law's authority and for my fellow citizens' legitimate anxieties by posting bail, or by accepting the reasonable conditions that the court attaches to my bail.

This line of argument shows that a system of bail, one that might attach conditions to the granting of bail, can be consistent with the PoI, once we understand the PoI in this context as a civic PoI that is qualified when a person is charged with a criminal offence. More precisely, it can justify a system of bail that treats all defendants, or all who are charged with the same kind of offence, equally. If decisions on the amount of bail, or the conditions to be imposed, are based on the court's judgement about how likely the individual defendant is to flee or to interfere (as they are now), they are liable to violate the civic PoI. For the decision to set bail high, or to impose strict conditions, expresses suspicion directed at the particular defendant, as distinct from other defendants; but the justification of a bail system offered here attaches suspicion to the role of defendant, rather than to the particular individuals who fill that role. What the court should say to a defendant is 'You must accept these requirements just because you are a defendant (facing a serious charge)': this makes clear that these burdens flow from the role that he must now play, and not from a particular suspicion of him as an individual. ${ }^{49}$ (We might add that if defendants are to be treated equally, the amount of bail required must be proportional to the individual defendant's means: a fair system of bail would be analogous to a system of 'day fines' or 'unit fines.')

This line of argument cannot, however, render a system of pre-trial detention consistent with even a qualified version of the kind of civic trust that is, I have argued, expressed in the civic PoI. To detain a defendant is not just to require him to offer reassurances, to allay the suspicions that reasonably attach to his role: it is to treat him as someone who simply cannot be trusted - cannot be trusted even to fulfil the conditions that might be attached to bail; but that is to cease to treat him as a citizen who has not (yet) been proved guilty of any crime. If a defendant is granted bail, and even if conditions are attached to his bail, he is still trusted: he is subjected to requirements and conditions to which non-accused citizens are not subjected; but he is trusted to obey those requirements and conditions (in the sense in which we are all trusted to obey the law), and to present himself for trial. But if he is denied bail, and detained pending his trial, he is denied even the quali- 
fied trust accorded to someone on bail; we treat him as someone who is entirely untrustworthy in relation to his pending trial. Thus if we are to justify pre-trial detention at all, we must justify it as an infringement of the PoI, which has significant implications concerning the conditions under which defendants can be detained, and the compensation that might be due to them for such an infringement of their rights. ${ }^{50}$ I do not deny that we might be able to justify a trial system which allows such PoI-infringing detention, in exceptional cases, as a matter of crime-preventive necessity. For suppose a court has very strong evidence that the defendant is guilty of the crime charged, and that if granted bail (even with restrictive conditions) he is very likely to abscond, or to try to interfere with the course of justice, or to commit other crimes of the same kind as the one he is charged with committing: surely the law should allow (indeed require) the court to detain him pending his trial. ${ }^{51}$ Perhaps it should - though further discussion is needed of how strong such evidence would need to be (and could be), and of the kinds of risk that we should expect ourselves and each other to accept as a consequence of maintaining the PoI. ${ }^{52}$ But we must remember that if we allow this we are infringing the PoI, the defendant's right to be presumed innocent until proved guilty 'according to law'; we therefore owe the defendant compensation, and also owe it to him to make sure that the conditions of his detention are as unrestrictive, and as distinct from penal imprisonment, as possible. ${ }^{53}$

\section{5 'Ex-Offenders,' Innocence Restored, and Collateral Consequences of Punishment}

A defendant who is found guilty becomes a convicted offender, thus incurring the various burdens and duties that belong with that role, including in particular the burdens and duties of punishment. But punishment, in civilized systems, normally has an end: the offender pays his fine, completes the specified period of probation or community service, or is freed at the end of his prison term. In the familiar rhetoric of liberal penality, he has 'paid his debt,' and has, we hope, been 'rehabilitated'; he is restored to civic community with his fellow citizens. This suggests that his role as 'offender' is over: in the eyes of the law, its officials, and his

50 The only conditions under which detention might be consistent with the PoI are, first, if the defendant tries to flee or to interfere with the trial process; and, second, if he has in the past fled or interfered with the trial: we could then argue that he has shown by his own conduct that he cannot be trusted in these matters.

51 Richard Lippke offered me the example of a defendant who has several prior convictions for rape with a distinctive MO, who is now charged with a rape that (according to the police evidence) involved the same MO, and perhaps also DNA evidence linking him to the crime: if there is strong evidence that he is indeed a serial rapist who is very likely to rape again if released on bail, are we really to say that the court must nonetheless leave him at liberty pending his trial?

52 The issues here are similar to those raised by provisions for the preventive detention of offenders who are judged to be 'dangerous': see my 'Dangerousness and Citizenship,' in Fundamentals of Sentencing Theory, ed. Andrew Ashworth \& Martin Wasik (Oxford: Oxford University Press, 1998), 141.

53 Compare HM Inspectorate of Prisons, Thematic Report on Remand Prisoners (2012), reporting critically on the conditions of pre-trial detention in the UK. 
fellow citizens, he is simply a citizen who is entitled, as are all citizens, to be presumed innocent of crime; his presumed innocence is restored by the completion of his punishment.

But that is not what happens (at least in Britain and the United States): a person who has completed his punishment, at least if he was in prison for a serious offence, becomes an 'ex-offender,' which is a curious role. On the one hand, 'ex-' suggests that this is not a role at all: it declares that the description which it qualifies no longer applies; he was an offender, but is no longer. On the other hand, as the phrase is actually used, it suggests that the taint of that - strictly speaking no longer applicable - description persists: the 'ex-offender' still carries the powerfully effective stigma of offending. ${ }^{54}$

Some of its effects are informal: depending on the environment to which the person now returns and the perceived nature of his crime, he might suffer various kinds of social hostility or exclusion. But others are legal, either mandated by law as automatic consequences of his conviction, or imposed more selectively by legal authorities. We can distinguish three salient types of legal consequence: all are 'collateral consequences of punishment' in the sense that, although not formally part of the offender's punishment, they are burdens imposed on him as a result of his conviction and punishment.

First, he may be excluded from aspects of civic life to which others have access. People with criminal records (of certain kinds) may be excluded from certain types of employment, or disqualified from certain activities. In the United States they can be excluded from welfare assistance, and from access to public housing. They can also be excluded from participation in civic life - from holding public office, from serving on a jury, even from voting (not just while in prison, but for the rest of their lives). ${ }^{55}$

Second, he may be subjected to supervision or monitoring, rather than exclusion. For just one example, anyone convicted in England of any of a list of sexual offences is placed on the 'Sex Offenders Register,' for a specified period or indefinitely (depending on the seriousness of the offence); this requires him to inform the police about where he is living or travelling. ${ }^{56}$

Third, the most drastic legal consequence is continued detention after whatever time was set as the punishment for the crime of conviction. One example is the

54 Compare the use of 'ci-devant' in revolutionary France: the 'ci-devant' comte or marquis was not simply an ex-aristocrat; he was still tainted by his past identity.

55 See, generally, Andrew von Hirsch \& Martin Wasik, 'Civil Disqualifications Attending Conviction,' Cambridge Law Journal 56 (1997): 599; Hugh LaFollette, 'Collateral Consequences of Punishment,' Journal of Applied Philosophy 22 (2005): 241; Mark Mauer \& Meda Chesney-Lind (eds.), Invisible Punishment (New York: New Press, 2002); I have learned much from Zach Hoskins, 'ExOffender Restrictions', forthcoming, Journal of Applied Philosophy.

56 See Sexual Offences Act 2003, Part II. Compare the notorious Megan's Laws in the United States, under which the state enables citizens to find out whether sexual offenders are living in their neighbourhood (see, e.g., www.meganslaw.ca.gov). 
English 'indeterminate sentence for public protection,' introduced in 2005, to be imposed on those convicted of any of a list of violent or sexual offences if 'the court is of the opinion that there is a significant risk to members of the public of serious harm occasioned by the commission by him of further specified offences': someone receiving such a sentence is kept in prison, beyond the term that provides a proportionate punishment for the crime of which he was convicted, until he can persuade a parole board that it is safe to release him. ${ }^{57}$

One question about such social and legal consequences of criminal conviction is whether they are imposed, and should be appraised, as further parts of the offender's punishment. If so, and if we accept the modest retributive claim that punishments should be proportionate to, or intrinsically appropriate as responses to, the offences for which they are imposed, we must ask whether the burdens that such provisions impose could be appropriate as punishments. I will not pursue that question here, but will attend only to measures that are supposed to be justified in preventive rather than punitive terms: measures that are imposed in virtue of a perceived risk that a person who has completed his punishment might go on to reoffend.

Nor will I discuss the most clearly unwarranted measures, such as exclusion from public housing or welfare support, or from voting. These can be seen as concrete manifestations of a conception of offenders as outsiders who have lost their standing as citizens - as members of the polity: 'three strikes,' as the American slogan so brutally puts it, 'and you're out.' There is a real question about whether there are kinds of offence, or of criminal career, so terrible, or so radically inconsistent with the minimal conditions of civic life, that those who commit such offences or persist in such careers must be taken to have excluded themselves from the civic life of the polity. ${ }^{58}$ But if there are any such offences or offenders, they are rare: if we take seriously the ideals of an inclusive democracy, we must in the overwhelming majority of cases see those who commit offences as fellow citizens who have done wrong, for which they must answer, but who still belong to the polity, and who must be restored to normal civic life through their punishment. That must include, at least, access to the kinds of welfare support that the polity offers its members, and to the vote.

If punishment ends with restoration to ordinary civic life, if the civic PoI is suspended for a time but not permanently defeated by criminal convictions, we must

57 See Criminal Justice Act 2003, ss. 224-36; and Peter Ramsay, 'A Political Theory of Imprisonment for Public Protection,' in Retributivism Has a Past: Has It a Future?, ed. Michael Tonry (Oxford: Oxford University Press, 2011). These sentences (versions of which are found in many countries) are being replaced by determinate 'extended sentences' (see Legal Aid, Sentencing and Punishment of Offenders Act 2012, ss. 122-28).

58 See my Punishment, Communication and Community, 170-74. To deal with this question, we would need to discuss the deeper conceptions of political community that underpin normative theories of crime and punishment: the exclusionary attitude displayed in 'three strikes and you're out' might be more congenial to a contractualist political theory, or to illiberal species of communitarianism. 
also reject detention as a post-punishment preventive measure - or at least mark it as inconsistent with the PoI and as thus needing to be justified, if it is justifiable at all, as an emergency measure which infringes the rights of those who are detained. Just as pre-trial detention contradicts, rather than merely qualifying or modifying, the civic PoI, so too does post-punishment preventive detention: for it says to the person detained that we do not trust him at all - that we are going to treat him as a continuing enemy whom we detain for our own protection; but that is not something that we can say to a fellow citizen. ${ }^{59}$ If someone is mentally disordered in a way that radically impairs his capacities for rational action, and renders him dangerous to others or to himself, we may detain him to protect those whom he would otherwise endanger, since we can no longer treat him as a rationally competent, reason-responsive agent; he lacks the capacities on which civic trust depends (and we must strive to help him to regain them). But absent any such radical impairment, we cannot subject a person to preventive post-punishment detention while still claiming to treat him as a fellow-citizen. ${ }^{60}$

(While I was writing this, a Norwegian court delivered its judgment on Anders Breivik, who killed 77 people in Oslo and on Utøya Island: not insane, guilty of 77 murders, and sentenced to the maximum possible punishment of 21 years in prison - although after he has served the punitive part of his sentence, set at a minimum of 10 years, he can be kept in preventive detention if he is judged to be still dangerous. This case challenges us all both intellectually and morally. It challenges the distinction between sanity and insanity: if sanity involves being competent to engage in rational thought and action as a member of a normative community, can we call such a person sane? It challenges our understanding of punishment: what kind of punishment could constitute an appropriate response to such a crime? It challenges our understanding of the ideal of an inclusive political community: can we really say, can we expect Norwegians to say, that Anders Breivik remains a citizen who must be restored to civic community once he has served his sentence? One way to see the force of that last question is to ask how Breivik himself, if we imagine him coming to understand his deeds for the terrible crimes that they were, could find a way to live again with his fellow Norwegians.)

However, when we look at other exclusions or restrictions that are justified in preventive terms, matters are not so straightforward. We should note first that the restoration to civic life which the end of punishment is supposed to bring makes significant demands, not only on the person who was punished and must now rebuild their life, but on all citizens: it requires us all to treat 'ex-offenders' with civic trust, to presume them to be innocent of harmful intentions, although

59 Compare Günther Jakobs, 'Bürgerstrafrecht und Feindstrafrecht,' HRRS 5 (2004) 88. We think we are justified in preventively detaining enemy soldiers during wartime, on the assumption that if they are released they will renew their attack on us: so too, if those who commit certain kinds of crime thereby define themselves as our 'enemies' in 'the war on crime' we detain them - although this war has no end in sight. That 'if' clause is what we must question.

60 I presuppose here that we can make warranted predictions of dangerousness, and can draw a suitably robust distinction between sanity and mental disorder: both presuppositions are of course contestable. 
we know that such trust is often empirically ill-founded; it requires us to accept the risk that we will be victims of future crimes by repeat offenders. ${ }^{61}$ This is a noble, demanding aspiration for our civic life. But does it really require us to trust each other unqualifiedly, as if we had never offended; or can the civic PoI be qualified by a citizen's past criminal conduct, which (we might say) gives us good reason not to trust him completely? ${ }^{62}$

One such modification would be to require the person to accept some kind of monitoring: this could involve active requirements (such as reporting regularly to the police), or passive impositions (such as wearing an electronic tag). The message of such measures is that we do not (yet) trust the person completely - not as completely as we trust those who have not been convicted of the kind of offence he committed: we trust him only so long as he is in this way monitored. In Britain learner drivers must be accompanied by a qualified driver; doctors who have made serious errors may be allowed to continue practising, but only under supervision: similarly, we would allow the person who has been punished to live in civil society only if he is supervised. Now some such treatment, some such message, can be justified: it is precisely what probation involves as a sentence passed after conviction. A sentence of probation says to the defendant that he has by his criminal conduct shown that he is not wholly trustworthy, and that he must therefore accept a period of supervision, to which further requirements may be attached, as a condition of his continued participation in the polity's civic life. If the length and onerousness of the probation is proportionate to the nature and seriousness of the offence, and the requirements are suitably related to the offence, this can be an appropriate sentence for many kinds of offence. ${ }^{63}$ What is crucial to such a justification of probation, however, is that it must be a proportionate response to the offence for which the person was convicted, which can therefore be justified as a deserved punishment for that offence: it is because the person has shown himself to be less than fully trustworthy that we are justified in requiring him to accept and cooperate with this supervision.

Probation as a punishment is, typically, determinate in duration: the offender knows how long he will spend on probation. There are good reasons for this - good reasons to resist any return to a system of indeterminate sentencing. Pun-

61 We must of course ask why so many who have offended and been punished then re-offend: to the extent that such re-offending can be attributed to the mode and manner of the punishments they suffered, or of their post-punishment treatment, the risks of their re-offending are risks that the whole polity should be more willing to accept (as having been collectively responsible for them) and try to remedy.

62 Such qualification would depend on the person's record being known at least to the relevant officials, if not to the public. The prohibitions that some European countries maintain on publicizing a person's convictions perhaps symbolize the restoration of civic trust that concerns me here (on the Spanish provisions, and their grounding in ideas of honour and privacy, see James B. Jacobs \& Elena Larrauri, 'Are criminal convictions a public matter? The USA and Spain,' Punishment and Society 14 (2012): 3: but we might note that even in Spain employers can ask job applicants 'to submit (...) an official summary of past convictions or (...) documentary proof of a clean record' (Jacobs \& Larrauri, p. 15)).

63 See further my Punishment, Communication and Community, 99-106. 
ishment, as an imposition which censures the person who is punished, must constitute an appropriate response to the offence that made the censure legitimate a response appropriate to the seriousness of that offence; the severity of the punishment conveys the severity of the censure that the offence merits; so the severity of the sentence imposed on the offender must be proportionate to the seriousness of his crime. Although one important aim of punishment should be reform or rehabilitation, restoring the offender (persuading and helping him to restore himself) to a law-abiding civic life, a proper respect for proportionality and for the offender as a responsible agent forbids us to extend the punishment until he is reformed: once he has completed the punishment, as a partly ritualized process of reparation, we treat him as (as if) reformed - although we know full well that this will often be a pretence. ${ }^{64}$ Thus if we are to reconcile a system of continuing supervision for offenders with the civic PoI, we must justify it precisely as a proportionate penal response to the offence for which the person was convicted. Perhaps this can be done, at least for those who persistently commit seriously harmful crimes: perhaps there are some offences of which we can say that someone who persists in committing them thereby justifies us in withholding anything but a highly conditional trust until he can show himself again to be trustworthy. But that is what we would need to do, since we cannot justify such measures in purely preventive terms. ${ }^{65}$

What of the other kind of collateral consequence noted above - exclusion from activities in which others can freely engage? We must distinguish here (though the distinction is neither neat nor uncontroversial) between activities that are an essential part of ordinary civic life and those that are not; among the latter, we must look especially at those that involve greater than normal risks of serious harms, especially to people who are particularly vulnerable. Exclusion from activities essential to ordinary civic life can be justified, if at all, only as punishment for past crime - imprisonment is the most obvious such exclusion: once the punishment is ended, the person returns to normal civic life; such exclusions from it cannot be justified as collateral consequences of punishment. This applies to both legal and informal exclusion: it would be wrong, for instance, for shopkeepers to refuse to serve someone who had been convicted and punished for an offence, or for others to exclude him from public spaces, just as it would be wrong for the law to exclude him. Of course, if a person has seriously misbehaved in a shop (or a restaurant) for instance, the owner might legitimately refuse to serve him; but the mere fact of having committed (and been punished for) past offences cannot justify exclusion from essential dimensions of ordinary civic life. We might, however, be able to justify exclusion, or disqualification, from activities that are not essential to ordinary civic life, and that involve special dangers and/or special vulnerabilities, on grounds that combine the punitive with the preventive. 
Such activities are typically ones for which a licence is required, which is obtained only given evidence of competence and suitability. Consider three examples. Drivers may drive unsupervised on public roads only after obtaining a licence, by passing a test. Doctors may practise only after successfully completing a long period of training and passing the relevant exams. In countries that control, without forbidding, the ownership of firearms, it is typically necessary to have a licence to own a gun - a licence that may be denied if there is evidence that one might misuse the gun, or fail to take proper care with it. All three activities involve significant dangers to others, sometimes to highly vulnerable others (patients needing medical care, for instance); all three require both competence and the exercise of special care. In all three cases, it is also true that the activity is not essential to participation in ordinary civic life: a citizen can lead a decent life without driving, being a doctor, or owning a gun. ${ }^{66}$

Licences that have been granted can be removed, given adequate evidence either of a loss of competence (a driver whose eyesight fails; a doctor whom illness or disability renders less able to practice efficiently), or of serious misconduct. A driver who persistently flouts road traffic regulations in ways that are likely to endanger others, or a doctor who persistently fails to take due care in treating his patients, is liable to be disqualified: the driver is liable to lose his licence; the doctor is liable to be suspended or 'struck off - disqualified from practising. Such disqualifications in response to misconduct can be seen in part as punishments, which aim to bring the wrongdoer to recognize the nature and implications of his conduct: in that case, their severity must be proportionate to the seriousness of the wrongdoing. But, at least in cases of persistent offending, they may be extended, to become indefinite or presumptively permanent exclusions from the activity in question, to protect others from the harm that the person might cause. ${ }^{67}$ What justifies such extended disqualifications is partly, of course, the perceived need to reduce this risk of harm, and this is the central justification in cases of loss of capacity or competence: if someone is unable to take part in a dangerous activity without unreasonably endangering others, we can legitimately forbid them to take part. But in cases of misconduct rather than incompetence, if we can suppose that the person is still capable of behaving safely and avoiding exposing others to unreasonable risks of harm, harm prevention cannot be the whole justification. What is also crucial is that we are no longer willing to trust him to behave safely, and what needs justifying is that withdrawal of trust.

What is now withdrawn is not the basic civic trust on which a polity depends: we do not presume that the person is or will be generally guilty of criminal conduct; he is indeed trusted to respect the decision to disqualify him, and to refrain from taking part in that activity. But we do not now trust him, as we trust others who

66 This might be doubtful in the case of driving, if there is a lack of adequate public transport: but such a lack undermines the justice of a strict licensing scheme; for those who are unable to obtain a licence, are thereby excluded from an essential dimension of contemporary civic life.

67 A further question that I cannot pursue here is whether a single breach could be so serious as to warrant an indefinite or presumptively permanent disqualification. 
have obtained a licence, to exercise due care in the activity. What justifies our withdrawal of trust is that by his own conduct he has shown himself to be untrustworthy; and whilst a wrongdoer who has undergone his punishment can expect to return to ordinary civic life and to regain the civic PoI, in the context of specific and dangerous activities such as these trust, and the presumption of good conduct which that trust involves, need not be so readily restored. A PoI still operates in these contexts: we presume that those who have gained a licence by passing the appropriate tests will conduct themselves with due care and attention to the risks involved. But that presumption is more easily defeated by misconduct than is the civic PoI, both because of the dangers involved in the activity and because it is not essential to a citizen's life in the polity. We should perhaps make it possible for trust to be regained, by providing a process through which the disqualified person could give us reason to believe that he has reformed - that is why I spoke above of disqualifications that are presumptively permanent, permanent unless the person gives us reason to lift them. But whereas a person who has undergone his punishment should normally be able to expect an unconditional return to civic life, the same need not be true of such more specialized, and dangerous, activities.

\section{Concluding Comment}

This paper has moved rapidly over a large number of topics, with the result that argument and explanation have often been replaced by assertion and gestural sketches. But I hope that I have done enough to show that we should talk of presumptions of innocence outside as well as within the criminal trial; that such presumptions are connected to the kinds of trust that we should show each other as fellow citizens; and that by attending to the different roles that we may play in relation to the criminal law (in particular those of suspect, defendant, convicted offender, and 'ex-offender') we can understand more adequately the roles such presumptions play in different contexts, and the ways in which they can be qualified or modified rather than simply defeated. 